\title{
DEVELOPMENT OF LOCAL ECONOMIC INDEPENDENCE THROUGH OPTIMIZING OF VILLAGE FUND MANAGEMENT
}

\author{
Zulkarnaini \& Dadang Mashur \\ Program StudyPublic Administration FISIP University of Riau, Kampus Binawidya KM 12,5 Simpang Baru Pekanbaru \\ 28293, Indonesia
}

\begin{abstract}
Currently villages in Indonesia are required to be able to give birth to quality economic growth and sustainable. Quality economic growth is a concept of strengthening and contribution contributed by the real economy sector in the village. Therefore, the development and empowerment of rural communities through the management of the Village Fund or Village Fund Allocation Fund must be balanced. Because to empower the potential of the village optimally and sustainably, funding for the village needs to be focused not only to build village, but more empowered to become a self-constructing village. This study aims to develop local economic independence through optimizing the management of Village Funds in Siak Subdistrict Siak District and any factors that influence the development of local economic independence. This research is a descriptive qualitative research with sampling technique used is snowball sampling. The research informant is the apparatus involved in the implementation of the Village Fund program and the community leaders who know the program. Data collection was done by interview and observation technique, after the data collected and then analyzed by using qualitative descriptive analysis. The results of research indicate that the development of village economy can be done by strengthening the performance of local economic institutions such as BUMDes through various aspects. To achieve this, an integrated movement between the community, BUMDes and the government is realized in the form of partnership. Activities that can be done is to optimize the function of central and local entrepreneurial institutions to support various efforts to inventory the potential of local economic resources. With the development of household industry activities, it will facilitate efforts to establish cooperation between local economic development institutions that exist and thus create a process of sustainable community empowerment of villages.
\end{abstract}

Keywords: community development, local economy, village fund assistance, management

\section{INTRODUCTION}

One of the development priorities of the Jokowi-JK Government for the period 20142019 is "to develop Indonesia from the periphery". Of course, what is built here is not just the outskirts of the city, but development really goes into rural areas. This determination has been realized in real terms with the flow of funds to the villages whose numbers are always increasing every year (Ministry of Finance, 2017). In the 2017 APBN alone, for example, transfers to regions and villages exceed the spending of existing Ministries / Institutions, some of which are in the form of Village Fund distribution programs.

The Village Fund Program basically aims to reduce the level of poverty, inequality and job creation in the village and is expected to contribute positively to national economic development simultaneously. In more detail this program is intended to provide the driving force of economic growth in the region, namely through working communities who will get a wage so that their purchasing power increases. Likewise for people who have local raw 298 
materials will get income. Infrastructure and facilities / infrastructure built will be able to increase agricultural production and facilitate the distribution of goods.

Village Fund Distribution which is getting bigger each year since the last three years has positioned the village no longer as an object but a subject of development. Based on macroeconomic calculations, Village Fund distribution has multiplier effect a large. Until 2016, distribution of Village Funds could trigger a reduction in the poverty rate by 1.27 percent. Data from the Central Bureau of Statistics in October 2015 stated that the poverty rate in the village was recorded at 17.89 million people and in September 2016 decreased to 17.28 million people (Ministry of Finance, 2017).

In addition to encouraging poverty reduction, Village Funds also have implications for aspects of employment and employment. There are two employment creation schemes based on the use of Village Funds, namely through the development and empowerment of rural communities. The allocation of the Village Fund provides employment opportunities for local residents and encourages self-sufficiency through active participation, both in the aspects of planning and implementation of development. Village funds used for infrastructure development in 2015 have been able to absorb at least 1,154,035 workers and in 2016 the number increased to $2,477,800$ people.

The figures above represent employment generated in the village through the use of Village Funds. This phenomenon proves that the absorption of labor contributes to reducing economic inequality through increasing income and purchasing power of rural communities (Rahmat, 2013). While through the community empowerment scheme, the Village Fund contributed to the opening of employment opportunities through community empowerment activists who in 2015 totaled 29,609 people. In 2016 the figure increased to 136,054 people.

In the midst of these statistically increasing figures, it was found that there was an imbalance in the use of this Village Fund. According to data from the Ministry of Villages, PDT, and Transmigration of the Ministry of Health PDTT (2017), the Village Fund for the last two years was used more for the implementation of village infrastructure development. The details of Village Fund utilization in 2016 were 81 percent for infrastructure development; 7.10 percent for means of meeting basic needs; 5.9 percent for community empowerment; 2.45 percent for government administration; and only 1.7 percent is used to develop rural economic potential. The rest is used for community development and environmental conservation. From this data it is clear that the orientation of the use of the Village Fund is still dominated by physical development compared to aspects of empowerment and economic development of the community.

Infrastructure development and community empowerment through the Village Fund should be balanced, if not more for the aspect of community empowerment. This is as stated in the Regulation of the Minister of Villages, PDT, and Transmigration Number 22 of 2017 concerning the Priority of Using Village Funds. The Ministerial Regulation concretely directs the Village Fund to be used for equitable development, reducing inequality and alleviating poverty. Here the role of the Ministry of Trade in PDTT is required so that the Village Fund can be optimized through four priority programs, namely the superior village products, villageowned enterprises, village embungs, and village sports facilities. The priority implementation of Village Fund use must be agreed upon in the Village Conference.

To empower the village's potential optimally and sustainably, funding assistance for villages should not need to be focused solely on building village infrastructure, but the funds are more widely used to empower rural communities so that they can become a village that can build itself (Ferriyandi, 2016). Therefore, according to him at least 15-20\% of the total amount of assistance Village Fund should be proposed for village community empowerment activities. This is so that rural communities are able to access economic advances or to create productive 
businesses as a way to alleviate poverty. In addition to the need for infrastructure development in the countryside, at the same time village communities must also be given direct advocacy on economic empowerment and access to economic progress that is currently growing.

Zulkarnaini \& Mashur's research (2017) states that funding assistance from the government in the form of Village Fund Allocation (ADD) sourced from the APBD in Sungai Apit Sub-District, Siak District, is widely used outside priority areas. In addition, the implementation of work that should be self-managed is carried out entirely by third parties or service providers. Not to mention the problem of collection and deposit of taxes on work funded with ADD not in accordance with taxation provisions. There is even an ADD that is used to fund spending outside of what has been budgeted in the APBDes. These facts show that community empowerment as a target group in the ADD program is not in accordance with the basic concept.

Village Fund governance is still not very effective in its implementation. Asni's (2013) research in Dayun District, Siak Regency stated that in terms of regulation there was a design of a specific grant that was too rigid. While in terms of planning the function of the institution is not working, the quality of planners is low, and the level of community participation is low. Then in terms of implementation, complicated regulations and the still low level of implementing HR. Furthermore, in terms of monitoring and evaluation, the lack of apparatus and the absence of indicators that can measure village performance.

In this era of regional autonomy the village continues to be demanded to be able to produce quality and sustainable economic growth. Quality economic growth is the concept of reinforcement and contribution contributed by the real economy sector (Wibowo, 2016). The real economic sector that grew and developed from the bottom due to the economic support of the people in the village. Economic growth from the bottom rests on two main things, namely to provide the widest possible opportunity for local economic actors to utilize local property resources in the framework of mutual welfare and increase economic actors to reduce unused production factors.

Providing opportunities as wide as possible is not enough only through treatment to open access to capital, but also access to production, access to distribution and market access. Capital access is opened and developed through affordable and flexible lending, access to production is developed through encouragement and support of local industry sectors based on local resources, and market access is developed through regulations and policies that ensure optimum conditions for development and development of rural economies.

\section{METHOD}

Implementation of this research uses qualitative methods used to describe and explain. The reason for choosing this qualitative method is the desire to analyze and get to know the problem and get a justification for the situation and practices that are currently taking place and verify the results and then obtain results, in order to make plans in the future. The qualitative method is basically a research procedure that produces descriptive data in the form of written or verbal words from people and observed behavior (Moleong, 2002). Qualitative approaches are rooted in data, and theories related to these approaches are defined as rules and rules to explain propositions or sets of propositions that can be formulated descriptively or proportionally. The technique used in obtaining informants in this study is a snowball sampling technique which is a technique for determining information sources such as rolling snowballs to find the most appropriate source of information in responding. After the data is collected 
from each research infoman, the triangulation method will be used by check and cross check on the results of the responses given by the research informants.

\section{RESULT AND DISCUSSION}

The main problem in reducing poverty in Indonesia today is that economic growth is not evenly distributed. This is evidenced by the high income disparity between regions. Besides being a fact that poverty is a causal relationship. For example, a high level of poverty occurs because of low per capita income, low per capita income is due to a low per capita investment, and a low level of investment per capita due to per capita domestic demand. So on, so that it forms a circle of poverty as a cause and effect relationship.

The poverty reduction program through programs in the form of direct community assistance with an empowerment approach is one form of alternative development that requires the community to be able to be independent in fulfilling their needs. Within this framework, the current empowerment-based community assistance program run by the government is through the village fund program. Village funds are principally the assistance provided by the government in the context of accelerating development in the village for poverty reduction, community empowerment, and strengthening village governance.

Based on this program, to overcome the problem of poverty a strategy must be chosen that can take sides and empower the community through economic development and improving the economy of the people. This program must be realized in strategic steps directed directly at expanding the access of the poor to development resources and creating opportunities for the lowest levels of society to participate in the development process, so that they are able to overcome the conditions of underdevelopment. In addition, efforts to reduce poverty must always be based on determining the right poverty line and on a clear understanding of the causes of the problem.

\section{Implementation of Village Fund Management and Utilization Village}

Fund programs are based on Law No. 6 of 2014 concerning Village Funds. This program marks the seriousness of the government to change the prevailing paradigm, namely the project approach is a program priority. This is done by consolidating community empowerment programs in various ministries / institutions. In addition to improving infrastructure, these funds are expected to increase the income of rural communities through innovative programs with the theme of community empowerment.

Siak Regency in the last two years has utilized the village funds simultaneously. The funds disbursed range from Rp. 750-800 million for each village in each year. Utilization of village funds during the 2015-2017 period in Siak District has been able to produce 31 units of clean water, 18 MCK units, 15 posyandu, 9 wells, 13 PAUD, 2 Polindes and 10 village bodies. This development can proceed because it is in line with the village's efforts to use village funds to reduce poverty, so that the government continues to accelerate the distribution of Village Funds so that they reach the village level as soon as possible. The mechanism for distributing Village Funds is carried out from the State Treasury to Regional Treasury from the Regional Treasury to the Village Cash. Distribution efficiency and effectiveness that has been carried out decentralized through the State Treasury Service Office (KPPN) since last year shows that 100 percent of the Village Fund can be channeled from the state treasury to the village.

The stages of village fund distribution in Siak District have been changed to 3 stages, which were originally 2 stages with loosening distribution requirements. Phase I Village Funds of 20 percent were channeled 100 percent in February from state cash accounts to regional general cash accounts. While the distribution requirements for Phase II and III are 40 percent each, the Regional Government submits a report to the KPPN in the form of: Phase II: 
Realization of Village Fund distribution and Consolidation of realization of absorption and achievement of Village Fund output in the previous year no later than 7 working days before the 4th week of June. Phase III: (1) Realization of Village Fund distribution through stage II which shows the distribution of Regional Cash to Village Cash at least 75 percent; and (2) Consolidation of absorption realization and output achievement that shows an average absorption realization of at least 75 percent and a minimum output achievement of 50 percent.

The development of the rural economic base in Siak District has long been carried out through various programs. But that effort has not produced satisfactory results as desired by the community. Various programs for economic development in rural Siak District that have been implemented include Village Economic Savings and Loans (UED-SP), Community Based Savings and Loans Institutions (LSPBM), Village Credit Agencies (BKD), Urban Poverty Reduction Programs (P2KP), and the UPK-PKP-PKK Program. To all programs to strengthen the economy in this village, the results have yet to show the expected conditions.

Currently the strategy is to strengthen the village economy through strengthening BUMDes. This program is one solution to release the dependence of rural communities on village fund assistance and to explore the potential that exists. BUMDes are business institutions that are managed by the community and village government and are no longer established by government instructions, not controlled by certain groups and in carrying out their business for the benefit of the strategic interests of the people in the village. In addition, village business institutions managed by the community and village government are formed based on the needs and potential of the village.

Table 1 indicates that there are six villages in Siak Subdistrict, Siak Regency that have received village funds in 2017. Physical and financial realization until the end of 2017 had reached $85.68 \%$ for the sub-district average. Generally the financial realization is still fluidative, there are some villages that reach almost $100 \%$ but there are also some villages whose realization is only $60 \%$.

Table. 1 Report on Physical and Financial Realization of Village Funds (APBN) Activities in Siak Districts in 2017

\begin{tabular}{|c|c|c|c|c|c|}
\hline \multirow[b]{2}{*}{ No. } & \multirow[b]{2}{*}{$\begin{array}{l}\text { NAME OF } \\
\text { VILLAGE }\end{array}$} & \multirow{2}{*}{$\begin{array}{c}\text { OF } \\
\text { BUDGET } \\
\\
\text { (USD) } \\
\end{array}$} & \multicolumn{3}{|c|}{ REALIZATION OF FINANCE (Rp.) } \\
\hline & & & $\begin{array}{c}\text { REALIZATI } \\
\text { ON OF } \\
\text { (USD) }\end{array}$ & $\begin{array}{c}\text { THE REST } \\
\text { OF } \\
\text { (USD) }\end{array}$ & $\begin{array}{c}\text { REALIZATION } \\
\text { OF FINANCE } \\
(\%)\end{array}$ \\
\hline 1 & 2 & 3 & 4 & 5 & 6 \\
\hline 1 & Langkai & $773,510,228$ & $542,780,050$ & $230,730,178$ & $70.17 \%$ \\
\hline 2 & Tumang & $781,735,800$ & $764,877,380$ & $16,858,420$ & $97.84 \%$ \\
\hline 3 & Merempan Hulu & $773,510,228$ & $465,034,573$ & $308,475,655$ & $60.12 \%$ \\
\hline 4 & Rawang Air Putih & $781,928,590$ & $764,418,420$ & $17,510,170$ & $97.76 \%$ \\
\hline 5 & Advance & $785,231,165$ & $720,301,550$ & $64,929,615$ & $91.73 \%$ \\
\hline 6 & Large & $807,919,274$ & $685,936,700$ & $121,982,574$ & $84.90 \%$ \\
\hline & TOTAL & $4,703,835,285$ & $4,703,835,285$ & $3,943,348,673$ & $760,486,612$ \\
\hline
\end{tabular}

Source: District Siak, 2018 
Although the realization and utilization of village funds is relatively good Siak Subdistrict, but in its implementation there are still many obstacles. The main problem is that almost all villages prioritize the use of village funds for the purpose of building and repairing various village infrastructure such as road semi conditions and cluvert boxes. On the other hand, budget posts for community empowerment programs, especially related to rural economic development, tend to be less noticed. This means that more funds are used for infrastructure development compared to community empowerment activities.

Table 2 below explains that in one village in Siak District (Buantan Besar Village), the budget for community empowerment was very small. Even from small ones, there are also activities that have been designed, such as the Agricultural Economic and Fisheries Business Training, not yet realized or not at all. Even though the budget for this activity is very small, which is Rp. 13.9 million of the total funds received Rp. 807 million. While the budget for road seminarization and construction of box culverts, the realization of the budget of Rp. 742 million has reached $100 \%$.

Table. 2 Report on Physical and Financial Realization of Village Funding Activities (APBN) of Buantan Besar Siak Village in 2017

\begin{tabular}{|c|c|c|c|}
\hline \multirow{2}{*}{ DESCRIPTION OF ACTIVITIES } & \multirow{2}{*}{$\begin{array}{c}\text { BUDGET } \\
\text { (Rp) } \\
\end{array}$} & \multicolumn{2}{|c|}{$\begin{array}{l}\text { FINANCIAL REALIZATION } \\
\text { (Rp.) }\end{array}$} \\
\hline & & $\begin{array}{c}\text { REALIZATION } \\
(\text { Rp) } \\
\end{array}$ & $(\%)$ \\
\hline 1 & 2 & 3 & 5 \\
\hline Shopping & Rp. 807,919,274 & Rp. $685,936,700$ & $84.90 \%$ \\
\hline \multicolumn{4}{|l|}{ Field of Administration Village Government } \\
\hline $\begin{array}{l}\text { The Field of Village Development } \\
\text { Implementation }\end{array}$ & Rp. 742,620,500 & Rp. 674,236,700 & $90.79 \%$ \\
\hline Semenisasi Jalan SK II & Rp. $178,457,500$ & Rp. $178,457,500$ & $100.00 \%$ \\
\hline Semicalization of Jalan Kp. Only & Rp. $178,457,500$ & Rp. $128,396,100$ & $71.95 \%$ \\
\hline Semenisasi Jalan SK IV & Rp. $178,457,500$ & Rp. $178,457,500$ & $100.00 \%$ \\
\hline Seminaryization of the Road Gg. Rumbia & $\operatorname{Rp} 62,985,400$ & $\operatorname{Rp} 62,985,400$ & $100.00 \%$ \\
\hline Box Culvert Jalan Gg. Salak & Rp. $72,131,300$ & Rp. $72,103,000$ & $99.96 \%$ \\
\hline Box Culvert Jalan Gg. Orchid & Rp. $72,131,300$ & Rp. $53,837,200$ & $74.64 \%$ \\
\hline \multicolumn{4}{|l|}{ Field of Community Development } \\
\hline Community Empowerment Sector & Rp. 65,298,774 & Rp. 11,700,000 & $18 \%$ \\
\hline $\begin{array}{l}\text { Training for Community Preparedness in Facing } \\
\text { Natural Disasters }\end{array}$ & Rp. $11,994,324$ & - & $0 \%$ \\
\hline $\begin{array}{l}\text { Training for Village Community Institutions } \\
\text { Management }\end{array}$ & Rp. $11,205,000$ & - & $0 \%$ \\
\hline $\begin{array}{l}\text { Agricultural and Fisheries Economic Business } \\
\text { Training }\end{array}$ & Rp. $13,921,450$ & - & $0 \%$ \\
\hline $\begin{array}{l}\text { Posyandu Cadre Training and Village Health } \\
\text { Workers }\end{array}$ & Rp. $12,678,000$ & - & $0 \%$ \\
\hline
\end{tabular}




\begin{tabular}{|c|l|l|r|}
\hline Capacity Building for Community Groups & Rp. $15,500,000$ & Rp. $11,700,000$ & $75 \%$ \\
\hline TOTAL & Rp. 807,919,274 & Rp. 685,936,700 & $\mathbf{8 4 . 9 0 \%}$ \\
\hline
\end{tabular}

Source: Siak District, 2018

The above phenomenon implies that the utilization of village funds is not as expected. The development of local economic independence has not become a priority of village fund managers. As a result, the ability of the poor to improve their standard of living from village fund program activities seems far from the goal of their implementation. For this condition, it is worth questioning the inter-institutional integration in the district / city to the village level, namely between government-political institutions, business / private world economic institutions and community institutions. Because with the existence of good government institutions, government policies and programs can be directed at empowering the people's economy, so that the community has access and control over local resources and in the decision-making system.

The non-functioning of the institution and coupled with the low level of community participation, made the utilization of the Village Fund experience disorientation. Where as philosophically in fact with the existence of this Village Fund the community can be more economical. First, because the budget given from the center is very large. Naturally, every year all the alleys or village roads in the villages are already in the condition of cast concrete or paving blocks or asphalt. This means that the village has a high bargaining position. Second, village consultations as high-level institutions at the village level have a strategic position, because village planning will progress or prosper the community starts from village meetings, the good and bad results of the village from a good planning process.

Another thing is that the priority that must be done has also been stated in the central government regulation through the existing rules. This means that physical development, nonphysical, BUMDs or transparency at the village level must be a holistic guide in coordinating between institutions and elements of society. Moreover, villages can cooperate with third parties according to existing regulations and may not violate the rules above. In addition there are regulations on village land that can be used as village assets and also become village assets to be utilized by the village in the framework of the welfare of its citizens.

\section{Development of Local Economic Independence through Village Fund Utilization}

Economic growth in villages is often slow compared to urban economic development. To anticipate this, two approaches are needed, namely: a) Community needs in making changes and preventing undesirable things, and b) Political will and the capacity of the village government with the community in implementing the development plans that have been prepared. One effort that can be done is by encouraging the movement of the village economy to develop towards the growth of community welfare. This was supported by the government with the issuance of Government Regulation No. 47 of 2015 which stated that the village had the authority to regulate its own resources and direction of development. The existence of this regulation opens village opportunities for autonomy in management, both institutional and economic resources.

Changes to the Village Fund distribution policy show the government's desire that village funds can be channeled as quickly as possible to the village. On the other hand, the Regional Government and the village are expected to be able to work immediately and 
complete their work including priority activities to reduce poverty. Facing a very slow situation of national economic growth, it is necessary to implement strategies to develop the economic independence of rural communities. So far, the most dominant factor that causes the lack of success in poverty alleviation is the power of creativity and innovation of the community and village apparatus in managing and running economic "machines" in the countryside.

The development of village economic resources in the use of village funds however requires innovation from the management. From the data retrieval, it was found that the innovations owned by Village Fund managers in Siak District actually already existed. But the innovation carried out can be said to be still "half-hearted", even often hesitant to be implemented. During the process of identifying the initial problems, for example, this innovation has been seen by making actual programs, but at the implementation stage they seem "afraid" to provide ideas and ideas in solving the problems faced. Whereas the problem solving found in the framework of utilizing the Village Fund is prerogrative rights program manager to complete it.

This condition is due to the high involvement of local elites, so that every innovation found must first be discussed with them. The lack of courage in the village fund program managers in carrying out their innovations is caused by high fear of errors in the solutions found. Moreover, it has become a habit that every innovation that will be taken must be discussed first with the local elite and then take its decision. Whereas the origin can be accounted for, the Village Fund can be used for whatever is needed by the village community according to the existing rules. Starting from the establishment of the Posyandu until the salary or honorarium of the manager is allowed to be used.

Every development activity carried out must be able to meet current and future needs. Utilization of Village Funds in an effort to develop economic independence carried out still does not meet the principles of sustainable development. There are at least three indicators that can be used to analyze the concept of sustainable development, namely economic indicators, indicators of social justice, and environmental indicators. Economic indicators require that the development carried out is the existence of economic growth aimed at the welfare of the entire community, which is carried out through innovative technologies that have a minimum impact on the environment. So far, the development that supports economic growth and community welfare is the development of rural road access to agricultural and plantation areas. The large amount of forest clearing for agricultural and plantation areas has a very positive impact on the people's economy, but indirectly also reduces the wide availability of forests that should be conserved.

For indicators of social justice, the utilization of Village Funds at first glance seems to have been fair enough. The thing that is used as a fair benchmark or not is the use of RPJMDes in carrying out development. The RPJMDes has been prepared in accordance with the wishes of the community in the Musrenbang. But the development carried out is still not evenly distributed. In addition to not being evenly distributed, the implementation of development also lacks attention to the socio-cultural aspects that develop in the community, such as cultivating mutual cooperation activities.

The leadership shown by the chief executors of the Village Fund program was actually quite good, despite the reality that not all of them had an education level. But it can successfully implement this program with its experience. However, many found failure of this program due to lack of knowledge from existing leaders. For example, in the matter of finding funds. Before disbursing, of course every village must follow the prevailing mechanism. For example, by preparing all the designated administrations that must be met first, such as the Village Budget (APB-Des). In addition, the files must also go through the administrative verification process. Only after that can it be raised to the Finance Section of the Village Community and 
Government Empowerment Agency (BPMPD) in the district for disbursement requests for the ADD funds.

Many village governments as managers and implementers of ADD do not understand the principles of village financial management as stated in PERMENDAGRI Number 113 of 2014 concerning Village Financial Management. Article 2 paragraph 1 emphasizes that village finance is managed based on transparent, accountable and participatory principles. In fact, the village government as formal leadership never involves the community in the form of decision-making processes, planning, implementation, and evaluation of the results achieved. This indication is reinforced by the case of the summoning of more than 30 village heads and 12 sub-district heads by the District Attorney (Kajari) Siak regarding alleged mark-up and misappropriation of village budget funds in 2015.

Another important aspect in utilizing Village Funds that are considered is the trust that spearheads the success of a program. Regarding the public's trust in the implementation of the Village Fund program in Siak District, it is still low. This is more because the implementers rarely disseminate the program. The community mentioned that only the initial activities were carried out by the implementing party by gathering the community in the village hall or village meeting hall. This socialization model seems ineffective because sometimes not all people are present to listen to the program's presentation. As a result there are still many people who do not receive information on the implementation of the Village Fund program which is intended for the economic development of the community. The failure in the socialization process will make this program only be followed by a handful of people without touching the whole community.

One factor that is not less important in the utilization of Village Funds is a matter of accountability. The village government related to the development administration as well as the financial manager of the people who are beneficiaries or target groups are less transparent in financial matters. This certainly makes it unclear about the use of the Village Fund which is intended primarily for community empowerment. As a result, public trust has diminished, therefore they suggest the sub-district to look for trustworthy managers. The goal is that all activities and activities can be accounted for to the target group.

Accountability or accountability in community empowerment towards the use of Village Funds has not been realized in accordance with community expectations. Whereas every village in accordance with the rules concerning the accountability report of the village head requires that at the end of each budget year the Village Head is obliged to prepare a Report on the Implementation of the Village Government and the Statement of Accountability at the End of the fiscal year and inform the people which includes information on the main activities. Conditions that occur in the field there are still some village governments who do not make accountability reports about the budget spent in utilizing the Village Fund. Therefore, there is a Village Fund that has been directly dismissed by the district government with a note because there is no accountability in every realization of the program.

After all, the use of Village Funds is important for collaboration between managers and target groups. This collaboration can be seen in the direct use of development results such as the construction of school buildings, the provision of clean water, and access to village roads. One of the results of development that has been carried out from the results of collaboration is when building a kindergarten building. The building that used to be damaged due to long neglected has been repaired by residents in mutual cooperation and self-help. Until now the building is still in good condition and clean because residents often clean the place alternately. 
Communication is important in achieving goals in the organization. The communication developed by the implementing party from the Village Fund program is still not going well. This means that the empowerment party has not been able to provide clear information and news about program implementation. The inability to communicate makes the program unable to be enjoyed by all village communities who are the target groups in this program. The lack of maximum communication from the Village Fund management organization makes community participation in the village activities financed also show unfavorable symptoms.

The most important communication process is conveying information or news about the community's economic development program implemented. Because with the clarity of the information conveyed to the public, it will certainly provide public knowledge of the community empowerment program provided by the local government. The reality in the field was that the information received by the community about the program was still not evenly distributed throughout the community. As a result, the implementation of activities has not been received evenly by the public.

\section{CONCLUSION}

Development of economic independence local through the use of Village Funds in Siak District, Siak Regency has not been optimal. It can be said that the funds disbursed through this program in the field of community empowerment, especially in the effort to develop the economic independence of local communities, have not been as expected. The fact is that most of the available funds are more widely used for infrastructure improvement and development compared to the activities of developing community economic independence. The dominant factor influencing the non-optimal utilization of the Village Fund is the inability of village apparatus in making local economic development programs that are in accordance with the needs of the community. This inability is due to the lack of clear instructions for anything and what is the ideal portion of village funds in the area of community empowerment and lack of innovation in planning activities to be made.

\section{REFERENCE}

Asni, Fauzi. 2013. Analysis of Management of Village Fund Allocation to Support Village Economic Independence in Siak Regency. Dissertation, Malang: Brawijaya University.

Ferryandi, 2016. Implementation of District and Village Financial Balance through the Independent Village Program for Strengthening Local Economy in Indragiri Hilir Regency. Dissertation, Malang: Brawijaya University.

Hariadi, Bambang. 2003. Management Strategy: Formulation of Strategies to Win Competition. Malang: Bayumedia Publishing.

Hardijono, Rachmat, 2013. Independence of the Village Economy through Institutions of Village-Owned Enterprises. Dissertation, Malang: Brawijaya University.

Kartika, Ray Septianis. 2012. Community Participation in Managing Village Fund Allocation (ADD) in Tegeswetan Village and Jangkrikan Village, Kepil District, Wonosobo District. Jurnal Bina Praja, Vol. 4 No. 3

Nugrianti, Oni and Zulkarnaini. 2013. Community Empowerment Through Fund Allocation Programs. Public Policy Journal. Vol. 4, No. 1

Nawawi, Hadari. 2003. Strategic Management: Non-Profit Organizations in Government. Yogyakarta: UGM Press. 
Rohmah, Kulia Tatik. 2016. Utilization of Village Fund Allocation in Increasing Infrastructure Development in Bektiharjo Village, Semanding District, Tuban Regency. Journal of Regional Autonomy Studies. Vol. 01, No. 01.

Salusu, J. 2008. Strategic Decision Making for Public Organizations and Non-Profit Organizations. Jakarta: PT. Grasindo.

Siagian, Sondang. P. 2002. Organizational Development. Jakarta: Bumi Aksara.

Sugiyono. 2006. Administrative Research Methodology, Bandung: Alfabeta.

Wahyudi. 1996. Public Management: Concepts, Applications and Implementation in the Implementation of Regional Autonomy. Bandung: Mandar Forward.

Wibowo, Lendy W. 2016. "Concept of Independent Villages". Village Tabloid. Issue 22. December 21.

Zulkarnaini and Dadang Mashur. 2017. Community Empowerment in Utilizing Village Fund Alocation through Institutional Strengthening in Sungai Apit District, Siak Regency. Research Report. Pekanbaru: LPPM University of Riau. 